\title{
厚朴七物湯の病態とその運用
}

\author{
福田 佳弘 $\mathrm{a}$ 岡 新治 $\mathrm{b}$ 小林 瑞 $\mathrm{c}$ \\ a 福田整形外科医院，鳥取，广680-0021 鳥取市材木町152 \\ おか内科クリニック，鳥取， = 680-0901 鳥取市江津407-2 \\ ～新宿海上ビル診療所つるかめ漢方センター，東京， $=151-0053$ 渋谷区代々木2-11-15
}

\section{Kobokushichimotsuto (Mongolia Seven Combination); Its Mechanism of Disease and Application}

\author{
Yoshihiro FUKUTA $^{\mathrm{a}} \quad$ Shinji OKA $^{\mathrm{b}}$ Mizuho KOBAYASHI $^{\mathrm{c}}$ \\ a Fukuta Orthopedic Clinic, 152 Zaimoku-cho, Tottori-shi, Tottori 680-0021, Japan \\ b Oka Clinic of Internal Medicine, 470-2 Ezu, Tottori-shi, Tottori 680-0901, Japan \\ c Shinjukukaijobiru Clinic, Tsurukame Kampo Center, 2-11-15 Yoyogi, Sibuya-ku, Tokyo 151-0053, Japan
}

\begin{abstract}
Based on our own 35 cases treated with kobokushichimotsuto as well as our predecessors' experience and their opinions, we investigated the drug's mechanism of action and its background indications. Our predecessors' opinions seem to be divided into two groups. Group A : An external pattern/syndrome (a keishito indication) of external contraction, followed by an interior heat pattern/syndrome (a kobokusammotsuto indication) appear. Mechanism of disease wise, this means that both external and internal patterns/syndromes exist at the same time. Because an internal pattern/syndrome is heavier than an external one, both patterns/syndromes are simultaneously treated, by making both medicinals bound together. Group B : Internal heat due to yang exuberance with yin debilitation is the mechanism of disease here. In group A, cause of disease is classed as a true heat pattern/syndrome. In group B, depending whether the internal heat belongs to either true heat or false type, deficiency and excess of pulse/abdominal patterns/syndromes change, and appetite differs. In either group, no peony is used to cope with the chest pattern/syndrome induced by the progression of gastric heat into the chest. Our cases consisted of upper respiratory illnesses with appetite loss, gastrointestinal diseases with chest oppression, respiratory diseases and intestinal obstructions. Kobokushichimotsuto, however, can be applied to neuroses, mental disorders and low back pains.
\end{abstract}

Key words : kobokushichimotsuto (magnolia seven combination), keishito (cinnamon combination), kobokusammotsuto (magnolia three combination)

要旨

厚朴七物湯が有効であった35症例と，先人の見解，治験例を礎とし，その立方の趣旨と病態を考察した。厚朴七 物湯に関する先人の意見は二群に分類される。A 群は，外感証に属し，外感による表証（桂枝湯証）に続して裏熱 証（厚朴三物湯証）が現れ，二証の併存した病態となるが，表証より裏証が重いため，その治法は二薬方の合方で 表裏双解である。B 群は, 陰虚内熱に起因し, その病態には厚朴三物湯の加味方が適応するとしている。そして内 熱が実熱証に属すか, 虚熱証に属すかで脈候, 腹候の虚実, 食思の程度が異なる。厚朴七物湯に菏薬が用いられて いないのは，胃熱の胸部への波及により現れる胸部症候に対応するためである。報告例は感冒に食傷を挟むもの， 腹満を伴う胃晹疾患, 呼吸器疾患, イレウス等であるが, 神経症, 精神疾患, 腰痛症にも運用が可能である。 キーワード：厚朴七物湯，桂枝湯，厚朴三物湯

\author{
緒言 \\ 厚朴七物湯の立方趣旨と病態について，先人の見 \\ 解は同一ではない。また報告例は極めて少ない。厚 \\ 朴七物湯証を厚朴三物湯と桂枝湯，あるいは桂枝去 \\ 䓎薬湯との合方証とするか，または厚朴三物湯加味
}

方証と診るかによりその運用は異なる。本論では有 効であった35症例と先人の解説，治験例を礎に，そ の病態を考察し適応を考える。

\section{条文の解釈}

本項では出典に記載されている厚朴七物湯の条文 
に対する先人の解釈を記述し問題点を指摘する。

\section{金匱要略・腹満寒疝宿食病篇}

病腹満, 発熱十日, 脈浮而数, 飲食如故, 厚朴七 物湯主之。厚朴半厅，甘草，大黄各三両，大霖十枚， 枳実五枚，桂枝二両，生姜五両。上七味，以水一斗， 煮取四升, 温服八合, 日三服。嘔者加半夏五合, 下 利去大黄，寒多者加生姜至半斤。

1 . 先人の解釈

概して A，Bの二群に分類される。

\section{a) $\mathrm{A}$ 群}

先に外感による発熱があり，後に腹満を病む。即 ち先に風寒による表証（桂枝湯証あるいは桂枝去药 薬湯証）に続いて裏熱証（厚朴三物湯証，あるいは 小承気湯証）が現れ，二証の併存となるが表証より 裏証が重いため二薬方の合方証とし，治法は表裏双 解である。

簡にして要を得た解説として金實要略直解の論述 を紹介する。

\section{1) 金實要略直解 1}

腹満とは, 内に実熱あるなり。脈浮にして数, 浮 は則ち風為り, 風は表邪為り, 故に発熱して十日, 数なれば則ち熱なり。熱すれば則ち穀を消すが故に， 飲食故の如し。下方を与へ, 腹満を蕩し表熱を除く なり。夫れ表裏俱に実すれば，当に先に表を解し乃 ち裏を攻むべし。今, 表邪微にして裏邪甚し, 故に 承気桂枝の二湯を相合わせて用る以て表裏を和す。 以下略。

\section{2 ) 同じ論旨の文献}

金匱玉函経二註 ${ }^{2)}$, 張氏医通 ${ }^{3)}$, 金潰要略論註 ${ }^{4)}$,

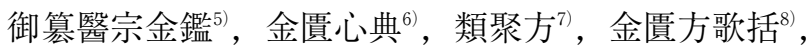
類聚方広義 ${ }^{9}$, 金匱発微 ${ }^{10}$, 金匱要略浅注補正 ${ }^{11}$, 李克光 $\cdot$ 張家礼主編金匱要略 ${ }^{12}$, 陳紀藩主編金匱要 略落。

\section{b ) B 群}

陰虚内熱に起因する諸症状が現れる病態と解説し ている。その嗃矢とすべき三因方の論述を引用する。

\section{1 ）三因極一病証方論 ${ }^{14}$}

厚朴七物湯は腹満し発熱するを治す。陽に陰が并 せらるを以て，則ち陽は実し陰は虚す。陽盛なれば 外熱を生じ，院虚すれば内熱を生ず。脈は必ず浮数 なり。浮は則ち虚と為す，数は則ち熱と為す。

厚朴姜製炒一両，甘草采，大黄蒸各三銭三字，枳実焚 炒去櫰半両, 桂心一分, 姜七片, 霖三個。嘔者加半夏一
分，利者去大黄，寒多加生姜十片煎。

この論旨の理解には “陰虚内熱” の認識が必要で あり，先にこの語句の出典と先人の見解を紹介する。 2 ）陰虚内熱の意義

素問・調経論第六十二に“帝曰く，陰虚すれば内 熱を生ずるはいかん。岐伯曰く，労倦する所あれば， 形気衰少し，穀気盛んならず。上焦行らず，下脘通 ぜず。胃気熱し，熱気胸中を熏ず。故に内熱するな り。”と記載されている。この語句に関する頭注医 経溯寧集の論述と黄帝内経・素問訳注の意訳を挙げ る。

頭注王履医経溯洄集 ${ }^{15)}$

此の陰虚の陰, 蓋し身中の陰気と水穀の味（栄 養）を指すのみ。或いは下焦の陰分を以て言と為し， 或いは腎水の真陰を以て言と為すは皆非なり。…... 穀気盛んならざる者, 元気を労傷するときは, 則ち 食を少なくし気衰ふなり。上焦行らざる者, 清陽升 らざるなり。下脘通ぜざる者，濁陰降らざるなり。 夫れ胃，水穀を受くが故に，清陽昇りて，而して濁 陰降り, 以て伝化出入して一身を滋栄するなり。今 胃納むこと能はずして穀気衰少すれば則ち清は升る ことなくして，濁降ること無きなり。故に，上焦行 らず，下脘通ぜずと曰ふなり。然れども，絶へて行 らず通ぜざるを謂ふに非らざるなり。但之を平常無 病の時に比ぶれば則ち行らず通ぜざるを謂ふのみ。 上行らず，下通じざれば則ち概するなり。概すると きは則ち少火，皆壮火と成る，而して胃は上焦下脘 の両者の間に居るが故に，胃気は熱す，熱すれば則 ち上炎す。故に胸中を熏じ而して内熱と為るなり。

筙に意ふに，内熱を作すは，皆陰火に非らざ るなり，但気が嘘すること有るときは，則ち熱を成 すのみと。

(1)少火 ${ }^{16)}$, 壮火 ${ }^{17)}$ : 少火は, 人体の生命活動を維持 するための正常な陽気を指し，壮火は人体の正気を 耗損するほど過度に克進した病的な陽気を指す。

(2)陰火：素問，霊枢，八十一難経には，この語句は 見当たらず，李東垣が『内外傷弁惑論』18)飲食労倦 論で始めて用いた言葉で，“心火は陰火なり，下焦 より起こり，……脾胃の気虚すれば，則ち陰火は其 の土に乗ず，……”論じている。中医大辞典 ${ }^{19)}$ に, “飲食労倦し喜怒哀楽の生ずる所の火を指し, 心火に属す。”との記載がある。 黄帝内経・素問訳注 ${ }^{20)}$ 
過激な労働により疲労倦怠を起こすと, 肉体は衰 弱し，その機能は低下寸る。そこで飲食物もよく取 れなくなって精気の生産も盛んでなくなる。精気を 十分に送り込めないので上焦の流通は滞り, 下脘す なわち胃の下部の働きも悪くなるので, 精気を抽出 した後の糟粕を大小腸に排出できなくなる。そのた め, 精気は胃に概滞し, 腐熟して病的な発熱を起こ すことになる。この熱気は胸部をくすべ，その中に こもる様になる。この様にして内部が熱するのであ る。以下略。

3 ）三因方の論旨に賛同する文献

筆者等が調べ得た限りでは世医得効方 ${ }^{21)}$, 金匱要 略本義, 方読弁解である。世医得効方の論説は三因 方と同文であり略す。

金嘈要略本義 22

脈浮数にして発熱するは，外感風邪の証に似たり。 浮数にして発熱するも, 却って頭痛項強悪風の証無 きを知らず，但腹満を見すのみなれば，則ち腹裏に

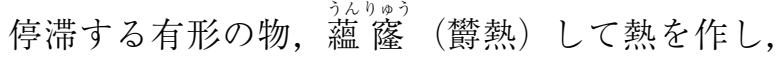
気外に向って洩れるは，脈，浮数を見し而して証， 発熱を為す所以。唯其れ外邪無きが故に中風の他証 を見ざるなり。

方読弁解 23

虚症の腹満に用ゆべし。……此の主治に, 誠に此 方意を尽くせり。陰虚する故に陽気浮きて発熱あり， 脈亦浮なり，此れ表邪に非ず，又実満に非ざること を知るべし。桂枝を用ゆるは，陽気を発起して外表 へ出さんが爲なり。此方凡て鼓脹に非ずして惟腹脹 る者に用るて効あり。(鼓脹門 ${ }^{23}$ には）此方意, 得 効方説に従ひ虚症の腹満に用ゆべし。厚朴三物湯の 症は実満なり。此症は飲食如故, 熱脹に属す者なり。 主治の発熱を以て表邪とするは非なり。〈原文〉

2 . 問題点

\section{a) $\mathrm{A}$ 群}

厚朴七物湯証を桂枝湯と腹満寒疝宿食病篇の厚朴 三物湯の合方証としての病態を考察する。傷寒論, 金貴要略に拠れば，太陽証と陽明証を交も病んでい る病態の治法は，併病の治法か或いは合方による同 治である。併病とすれば治の先後が問題となる。太 陽証と陽明証の併病については，条文の冒頭に“二 陽の併病”を揭げる太陽病篇 48 条と陽明病篇 220 条, さらに桂枝湯証, 麻黄湯証と陽明病の併病を説く 234，235条は治の先表後裏を説いている。即ち
234，235条は “陽明病”を冠しているが，陽明病の 薬方を指示せず, 桂枝湯, 麻黄湯の各証と腑病に至っ ていない陽明証の併存を説いている。また48条は“若 太陽病証不罷者, 不可下, 下之為逆。”とし，220条 は“太陽証罷，……之則愈。として証の軽重を 説き大承気湯を指示している。したがって太陽と陽 明の併病は先表後裏である。しかし, 厚朴七物湯証 は表証と陽明腑病の承気湯証との併存であるが，裏 証が表証より重い病態であるため, 治法は二薬方合 方による表裏双解である。なお，本方の薬量は各原 方とは異なり，桂枝湯証，厚朴三物湯証そのものの 併存ではなく近似証の併存である。ちなみに併病と 合方との相違を認識するには，48条，220条に記載 されている “罷”の字義の理解が必須である。その 字義を字統 ${ }^{24}$ は, “つかれる, やむ。と解説してい る。合病を説く条文には “罷”の字の記載はない。

さて本条にみられる“脈浮” は桂枝湯証, “発熱 ・腹満” は厚朴三物湯証の各々に近似した症候とし て解すべきである。“脈浮而数”の “而”の字義は, 時間的経過を意味し, 当初から浮数ではなく, 発熱 して日を経て “浮”に“数”が加わったものである。 張氏医通の説く, “発熱は，陽気が外に達するなり。 病十日経ると雖も，而るに脈浮数とは，邪が猶未だ 全て裏に入らず，況や能く食し以て胃気の有権を証 す。”には疑問を抱く。湿熱の㱆滞に因り，十日間 の経過中には, 多少とも脾胃が損傷を受け食思が妨 げられる病態もあると推考する。厚朴七物湯証では, 表証としては“脈浮而数”であり, “腹満, 飲食如 故”を勘考すれば，主たる証は裏に在る。即ち厚朴 三物湯証は桂枝湯証より重い病態であり, 厚朴三物 湯証を重視すべく药薬を去ったものと考える。小承 気湯とその類方の病態の概要を述べる。各条文と薬

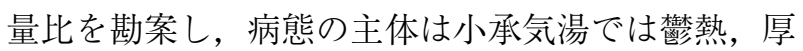
朴三物湯では気滞, 厚朴大黄湯では水滞と考える

\section{(表 1, 図 1)。}

\section{b ) B 群}

先掲の頭注医経溯洄集の解説と黄帝内経素問訳注 を基に，陰虚内熱に由来する厚朴七物湯証を勘案す る。“院虚すれば内熱を生ず。とは，精気が胃に停 滞し, 胃の機能が病的に光進あるいは低下し, 虚実 の相異はあるが病的な内熱が生ずる症候である。頭 注医経溯洄集は, “陰虚の陰は, 身中の陰気と水穀 の味 (栄養) を指すのみ。……但気が鬱すること有 
表 1 小承気湯とその類方の薬量

\begin{tabular}{llll}
\hline & 大黄 & 厚朴 & 枳実 \\
小承気湯 & 4両 & 2両多 & 3枚炎 \\
厚朴三物湯 & 4両 & 8両 & 5枚 \\
厚朴大黄湯 & 6両 & 1尺 & 4枚 \\
\hline
\end{tabular}

るときは，則ち熱を成すのみ。”説いている。病 の発症機転からみて, 陰虚には相対的な虚と絶対的 な虚があると考える。前者は陽気の病的光進に比し 陰が相対的に不足することを謂い，したがって内熱 は実熱に属し，後者は，陽気の過剩な病的忘進によ り津液は耗損し絶対的な不足に至るを謂い，則ち虚 熱に属す。ちなみに, 医経解惑論25) は “内熱, 宿食 が結実すれば則ち裏実を為す。と述べている。こ のように，内熱が実熱に属すか，虚熱に属すかによ り, 浮脈, 腹満の虚実, あるいは食思の程度は異な る。実熱に属せば, 浮脈は実脈であり, 粪便の聚結 による排便が滞り実満を呈する。さらに実熱の上逆 により胸満則ち胸部に不快感，閉塞感などが現れる。 翻って虚熱に属せば，浮脈は虚脈であり，陽気の不 足により蠕動運動は低下して排便は遅延し, 腸中に 腐敗物が堆積して脹満を現わし，また虚熱の上泛に よる胸満が現れると考える。この現象は, 急性, 慢 性を問わず内因性疾患に於ける大柴胡湯や大承気湯, あるいは真武湯，四逆湯の効能から首肯される。

c）小括

以上により厚朴七物湯証には, 外感による $\mathrm{A}$ 群 と陰虚内熱による B 群の二説がある。その相異は, 厚朴七物湯条の “飲食如故” の “故” の字の解釈如 何に拠ると考える。“故”の字は，本方証の発現す る前の食思が平素と変わりないか, 或いは既に胃腸 の機能障害により, 病的に充進し, 若しくは減退し ていることを指しており，“脈浮而数”とともに， 本方証が $\mathrm{A}$ 群， $\mathrm{B}$ 群のいずれに属すかのキーワー ドである。発病前に食思が正常とすれば本方証は A 群に属し, 胃腸の機能障害があれば $\mathrm{B}$ 群に属す場 合が多い。したがって厚朴七物湯証には外感に由来 する $\mathrm{A}$ 群と院虚内熱による $\mathrm{B}$ 群の二種類があるよ うに考察される。

\section{先人の治験例}

本項では, $\mathrm{A}$ 群の外感に由来する症例と, $\mathrm{B}$ 群の 陰虚内熱による症例を分けて呈示し, その治療経過

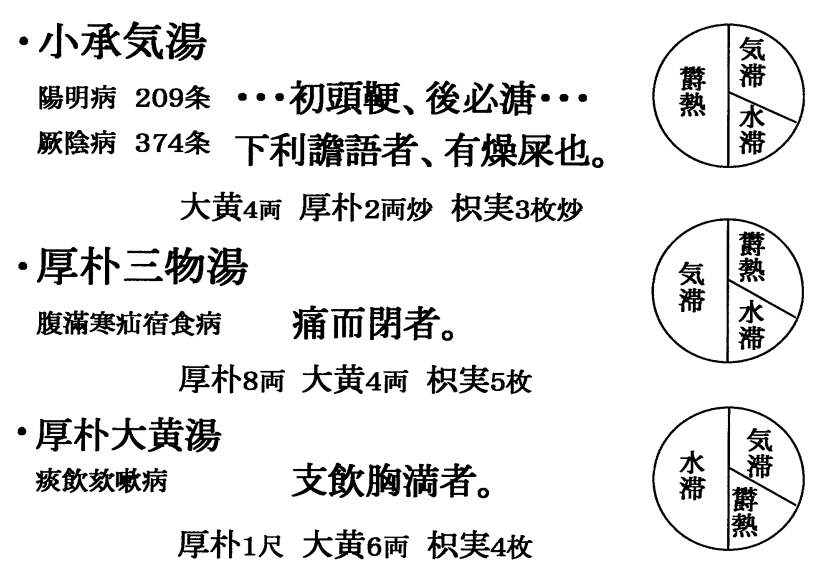

図 1 小承気湯とその類方の病態

を検討する。

1. A 群：外感に由来する症例

第 1 例 ${ }^{26)}$ 男子 7 歳

一月二十三日初診, 数日前から流感にかかり他医 の治療を受け，一時的に解熱したが今日再び三十八 度七分に発熱, 頭痛を訴えるという。下口唇赤く乾 燥し, 腹満を認める。脈寸は中等, 尺は強し。頭痛 を表熱桂枝の証とし, 尺緊, 腹満, 下口唇赤きを陽 明の熱として承気の証として，厚朴七物湯二分の一 量を投与，幸いにして一日分で解熱した。以下略。

(原文)

厚朴 $2.5 \mathrm{~g}$, 甘草, 大黄, 大霖各 $1 \mathrm{~g}$, 枳実 $1.2 \mathrm{~g}$, 桂枝 $0.5 \mathrm{~g}$ ，ひね生姜 $1.5 \mathrm{~g}$ 。

第 2 例 ${ }^{27)}$ 男性 43 歳

労働により汗をかいた後に涼んだ。そして夕食で 過食した後, 発熱悪寒, 頭疼, 筋肉痛, 胃部不快感, 悪心があり，蕉香正気丸，保和丸を服用したが薬効 がみられなかった。依然として発熱頭痛し, 汗出悪 風があり，腹満して痛み，便秘が三日間続いていた。 舌苔は黄淢，脈は浮にして滑であった。この病態は， 表に邪が残存しているが裏に邪が実しており表裏双 解による治法とした。厚朴 $10 \mathrm{~g}$, 枳実 $6 \mathrm{~g}$, 大黄 $10 \mathrm{~g}$, 桂枝 $10 \mathrm{~g}$, 甘草 $3 \mathrm{~g}$, 生姜 3 片, 大呆 3 枚に白药 $10 \mathrm{~g}$ を加え, 二剤を嘱服させ暢下を得て後, 糜码にて自 養し，上の症状は悉く除かれた。

2. B 群：陰虚内熱による症例

第 1 例 ${ }^{28)}$ 小腹脹満と胸満気喘

男性，50歳。肺気腫喘息を患い，毎に治療を経て 寛解していたが, 復び少腹脹満に因り胸満気喘を引 き起こし呼吸が暢びず，輾転反復すること数回。厚 朴七物湯の二剤を投与して気を行らし満を泄らし， 
桂枝を大いに増量し温陽建中とした。服薬後は泄下 せず，ただ腹脹のみ頓に消え，胸満気促は漸次好転 した。その後, 肺気腫は未だ治癒していないが, 腹 脹は概ね現れていない。

\section{第 2 例 ${ }^{28)}$ 胸満と腹脹満}

女性, 52歳。胸満, 呼吸促迫があり, 顔面は赤く 灼熱し, 腹部は大きく脹満し, 喉は梅核のようにな り，病むこと四年の久しきにわたっていた。毎に食 事の後には, 脹満が更に甚しくなり, 小便は短くて 赤く，大便は暢ではなかった。湿熱が腸胃に壅結し， 水道は不利し, 臓気は行っていないと診断した。厚 朴七物湯加木通 · 車前子 - 猪苓の二剂を投与し諸証 は明らかに好転し,ささに六剤を服して治癒した。

第 3 例 ${ }^{29)}$ 不明熱と腹満をともなう精神疲労

農家の子，二十歳ばかり，石尊詣でてょり帰りて， 寒熱勞（往来寒熱する結核性疾患）の如く, 顏色衰 え瘦せ, 腹満少気し, 衣の前合せず。青絡脈, 乳下 より不容の辺り (前胸下部), ヘチマのごとし。常 に暗室に座し客を見ることを欲せず，脈微数なり。 難治なり。ひそかに其の父に之を告げれば，その父 頗る才気あるものにて, 曰く, 其れ小病にあらざる を知る故に，遙かに枉駕を气ふ。中略。急にも死す まじと厚朴七物湯を与えて去る。後に, 薬を乞ふて 曰く, 餘程快しと。……前剂を与ふ。又數日を経 て再診を气ふ。予先に難治と思ひ定めれば，再診す るにも及ばずと答ふ。其の使頻りに快き所を見せて 加減を气ふと云ふ。故に辞を飾るとは思へども強い て命駕して行きて見れば，病者軽々と堂上に出迎ふ。 予驚きて診すれば，腹満消え常の腹なり。寒熱やみ て元気清爽，……何故に斯の如き早く治したるや， 今に於いて解せず〈原文〉。

\section{第 4 例 ${ }^{30)}$ 腸閉塞}

3 カ月の嬰児。間欠的に泣き叫び，腹部は脹満し (腹痛があったと思われる。) 三日間排便していな かった。以後は黄色の大便様の物を吐出し, 症状は 日益しに劇化し診察を受けた。西医の検査では完全 性腸閉塞と確診された。浣腸, 胃管による対象治療 では好転がみられず，手術療法の採用となった。患 者の家族は，小児が僅か 3 カ月であることを考慮し， 手術に同意せず，中医に診治を請うた。来院時，患 児は面色蒼白, 精神萎糜し, 時に冷汗を出し, 腹脹 して拒按し, 大便は通ぜず, 脈微で舌苔は死白色で あった。脾陽が運らず，積滞の内停によるものと診
て, 治は行気泄満, 温中散寒とし, 厚朴七物湯 (厚 朴 $10 \mathrm{~g}$ ，桂枝 $7.5 \mathrm{~g}$ ，甘草 $10 \mathrm{~g}$ ，枳実 $10 \mathrm{~g}$ ，大黄 $2.5 \mathrm{~g}$, 生姜 $5 \mathrm{~g}$ ）を用いた。服薬後 $1 \sim 2$ 時間ばかりして 大便様の膿塊を排出した。その後暫くして 3 回稀便 を排出し, 漸次腹脹は消失し, 腹痛は軽減し, 十余 日を経て治癒した。(大霜の記載なし)

3 . 治験例の考察

a) $\mathrm{A}$ 群

第 1 例では, 桂枝湯証と承気湯証との併存にみら れた熱候が厚朴七物湯で治っている。第 2 例では, 外感風寒による表証と食滞による陽明証との併存が 厚朴七物湯の加味方で治癒に至っている。食滞には 大黄の増量により瀉下作用を強め, 表証の汗出には 桂枝の増量と白䓎の加味により解肌の促進を図って いる。

\section{b ) B 群}

第 1 例の少腹脹満による胸満気喘は, 内熱の上逆 による症候である。やや寒涼の瀉下剂である厚朴七 物湯により胸満気喘が軽減した。その後, 直ちに桂 枝を増量して温性の瀉下剤とし, 腹脹は急に消え, 胸満気促は次第に良くなっている。この経過からみ て, 厚朴七物湯投与前の病態は虚実寒熱が混淆して おり, 先急後緩の治法により, 先に熱実証を後に虚 寒証を治したものである。この治法 ${ }^{31}$ は少陰病と陽 明病の併病で急下を説く大承気湯条 $(320,321,322)$ と急温を説く四逆湯条（323）に倣ったものである。 第 2 例の症候は内熱による実熱証に属し, 湿熱の上 逆による顔面潮紅, 胸満, 呼吸困難, また湿熱の隹 塞による小便の短少・濃縮, 大便の燥堅などの症候 が現れたものと考える。そして木通, 車前子, 猪苓 を加え清熱利水作用を強めている。第 3 例は僅か数 日間の厚朴七物湯投与により諸症候が快復している。 病状経過から推して過度の疲労による㮾状態にあっ た心身症と考える。慢性化した雑病による䇔瘦なら ば, 回復に相当日数を要したと思われる。第 4 例で は, 厚朴, 枳実, 大黄の薬量比は原方と同じである が, 桂枝, 甘草が約 2 倍である。“面色蒼白, 精神 萎糜し, 時に冷汗を出し.......” はイレウスの劇痛に よる仮寒証であり虚寒証ではない。虚寒とすれば, 厚朴七物湯投与によって大便様の膿塊の排出を見た 後に, 即時に四逆湯などの温裏剤による補陽が不可 欠であるが, 厚朴七物湯の継続服用により治癒に 至っている。 


\section{c）小括}

先人の治験例を $\mathrm{A}$ 群 (外感に由来する症例), $\mathrm{B}$ 群（陰虚内熱による症例）に分けることにより病態 及び治療経過が簡明に理解されると考える。

\section{自験例}

本項では最初に著効が認められた基本的な 3 症例 を呈示してその病態を検討し, 次に他の32症例につ いて概略を述べその治療効果を検討する。

1. 三症例の呈示

\section{第 1 例 72 歳 女性}

[主 訴] 腰痛, 腹満, 便秘。

[既往歴 $] X-33$ 年，卵巣を摘出。X-29年，ネフ ローゼ症候群を発病。X-19年 9 月，血液透析を開 始。同年10月腹膜透析に変更。 $X-18$ 年, 急性肝炎 を併発。X-14年, 腹膜透析に起因するイレウスの 併発により血液透析に再変更。 $\mathrm{X}-7$ 年, 副甲状腺 摘出。

[現病歴 $] X-14$ 年以来，被囊性腹膜硬化症による イレウスを併発し続け，頑固な便秘に苦しみ，それ とともに腰痛が次第に増悪している。近年は $0.75 \%$ ピコスルファートナトリウム水和物 20 滴, センノシ ド（12 mg） 4 錠を 2 2 日に 1 回服用し排便して いる。X年 9 月，当院を受診した。

[初診時所見]

〈自覚症〉全身倦㤐感，冷え性で足がよく冷える。 便秘と腹満がある。食欲不振, 食味不良。睡眠, 浅くて多夢。無尿。大便：下剤服用後, 便意を覚 えるも排泄が困難である。また排便前後に下腹部 痛, 残便感がある。性状, 硬便〜軟便, 汁状, 時 に兔糞状の便が混在する。

〈他覚所見〉身長 $148 \mathrm{~cm}$, 体重 $43 \mathrm{~kg}$, BMI19.6。全 身の皮膚は枯燥し，顏色は淡い褐色を呈している。 脈候：透析のため内シャント造設術を受けており 診断不能。足背動脉は浮弱ときに沈弱。舌候：舌 体はやや萎縮。背部はやや薄い白黄淢苔, 腹部は 淡紅色, 舌小帯近傍の静脈拡張し, 舌深静脈はや や膨化し微に灰白色を呈する。胸腹候 : 横隔膜に 近接する胸骨両傍の肋間部に按圧による不快感と 鈍痛，剣状突起下から胸膈に向けての按圧により 胸部㾂塞感が自覚される。腹壁全体は軟弱。心下 㾂 $(+)$, 臍上深部の拍動 $(+)$, 臍下不仁 $(+)$, 胃部振水音 $(+)$ 。腰背部候 : L 4 5 高位の旁 腰椎筋，両仙腸関節部の按圧痛 $(+)$ 。腰部・両

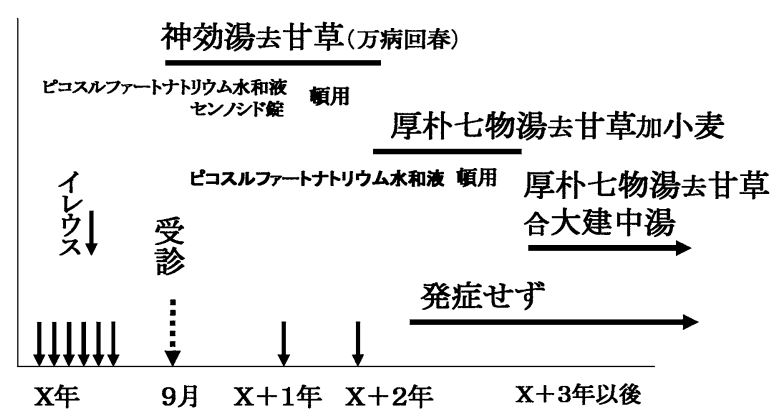

図 2 自験・第 1 例の経過

下肢には神経学的所見を認めない。

[経 過] 当初は, 自覚症状, 舌候, 臍上深部の搏

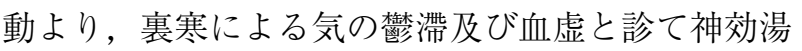
去甘草 (万病回春・頽疝門) を，また腎虚による腰 痛として仮称腎虚腰痛方（備急千金要方・腰痛門 · 薬方名の記載は無い) を投与した。 X+ 2 年 3 月, 腰痛は軽減したが腹満, 便秘の回復傾向は少なく, 他覚的に胸満が認められたため厚朴七物湯去甘草加 小麦に転方した。大黄の量を加減（1～2 g) しな がら適時, 郁李仁 $3 \mathrm{~g}$ を追加している。転方後はイ レゥスの発症はなく, $\mathrm{X}+3$ 年以後, 大建中湯との 合方で経過は良好である（図 2 )。

* 神効湯去甘草: 蒼术, 香附子, 當歸, 木香, 延胡 索, 益智仁, 烏薬, 山栃子, 縮砂各 $2 \mathrm{~g}$ 茴香, 生 姜, 呉荣鄚各 $1 \mathrm{~g}$ 。

*仮称腎虚腰痛方: 烏頭末 $0.13 \mathrm{~g}$, 桂皮 $2 \mathrm{~g}$, 牡丹 皮 $1 \mathrm{~g}$ ，蜂蜜 $4.5 \mathrm{~g}$ (丸薬として)

（八味丸から滋潤剤, 利水剂を去った処方であ る。)

*厚朴七物湯去甘草加小麦 : 厚朴 $8 \mathrm{~g}$, 枳実 $4 \mathrm{~g}$, 小

麦 $4 \mathrm{~g}$, 大黄 $1 \mathrm{~g}$, 大霜 $2 \mathrm{~g}$, 桂皮 $2 \mathrm{~g}$, 生美 $1 \mathrm{~g}$ 。 *大建中湯：蜀椒 $2 \mathrm{~g}$, 乾姜 $4 \mathrm{~g}$, 人参 $3 \mathrm{~g}$, 膠飴 $10 \mathrm{~g}$ 。

第 2例 61歳 女性

[主 訴] 胸部不安感, 腹満, 便秘。

[既往歴］5 年前より高血圧症のためアムロジピン $5 \mathrm{mg}$ を服用中。

[現病歴 $] X$ 年 9 月下旬, 某大学病院で子宮脱の手 術。10月初旬より不眠, 不安感に苦しみ同病院精神 科で輠状態と診断され，パロキセチン塩酸塩水和物 $20 \mathrm{mg}$ ，ロフラゼプ酸エチル $1 \mathrm{mg}$ ，塩酸トラゾドン $25 \mathrm{mg}$ を服用中である。同月下旬に当院を受診した。 [初診時所見］

〈自覚症〉四六時中，気分が落ち着かず，イライラ し気分がすぐれず，全身倦㤐感，腹満を覚え，胸 
が締め付けられるような気持ちがする。食欲減退。 小便 $5 \sim 6$ 回/日中, 夜間尿はない。大便，1 回/ $2 \sim 3$ 日, 残便感が著しく, 便臭が強い。睡眠, 浅くて多夢。

〈他覚所見〉身長 $153 \mathrm{~cm}$, 体重 $57 \mathrm{~kg}$, BMI 24.3 。顔 色はやや蒼白く, 挙措を失い, 家人が付き添って いる。脈候：浮やや弱, 時に弦。舌候：微黄色の 厚い白湿苔, 舌深静脈の萎縮を認める。胸腹候： 横隔膜に近接する胸骨両傍の肋間部に按圧による 不快感と鈍痛, 剣状突起下から胸膈に向けての按 圧により胸部㾂塞感を訴える。腹壁は軟, 微かに 膨満し心下㾂を触知する。

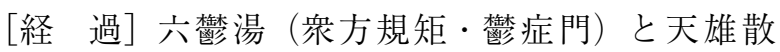

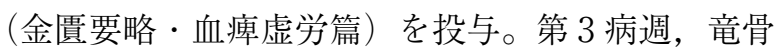
湯（外台秘要 - 風驚恐失志喜忘及妄言方）合四物湯 に転方するも無効。第 5 病週，便秘の好転はみられ ず，胸満の症状が重いため厚朴七物湯に転方した。 第 7 病週, 胸部不快感, 腹満は消失し便通は円滑と なった。その後, 現代医薬を漸次減少させ, 第17病 週には不要となり，第24病週に廃薬した。

*六榃湯：陳皮 $3 \mathrm{~g}$, 半夏, 蒼术, 川芎各 $4.5 \mathrm{~g}$, 山 柧子, 获苓各 $2 \mathrm{~g}$, 香附子 $6 \mathrm{~g}$, 甘草, 縮砂各 $1.5 \mathrm{~g}$ 。 *天雄散：烏頭 $0.1 \mathrm{~g}$, 白术 $0.4 \mathrm{~g}$, 桂皮 $0.3 \mathrm{~g}$, 龍骨 $0.1 \mathrm{~g}$, 蜂蜜 $2.5 \mathrm{~g}$ (丸薬として)。

*竜骨湯合四物湯：龍骨 $6 \mathrm{~g}$, 桂皮, 遠志, 麥門冬 各 $3 \mathrm{~g}$, 牡蚛 $6 \mathrm{~g}$, 甘草 $1.5 \mathrm{~g}$, 生姜 $1 \mathrm{~g}$, 获苓 $4 \mathrm{~g}$, 当帰，川芎，赤药，乾地黄各 $3 \mathrm{~g}$ 。

*厚朴七物湯: 厚朴 $8 \mathrm{~g}$, 枳実 $4 \mathrm{~g}$, 大黄 $1 \mathrm{~g}$, 大霖 $2 \mathrm{~g}$ ，桂皮 $2 \mathrm{~g}$ ，采甘草 $2 \mathrm{~g}$ ，生姜 $1 \mathrm{~g}$ 。

第 3 例 68 歳 女性

[主 訴] 胸部不快感・腹満・残便感を伴う便秘 [既往歴］気管支喘息を治療中（塩酸プロカテロー ルを吸入中)。

[現病歴］10日ほど前から, 腹部の膨満感, 残便感 を覚え, さらに 4,5 日来, 胸部に㾂塞感, 不快感 を覚え，身体が気怠く，気分がすっきりしない。X 年 1 月，当院を受診した。

[来院時所見］

〈自覚症〉腹が張るにもかかわらず，放屁は少なく， 重苦しく，気分がすぐれない。便意を毎日覚える も，排泄は 2 日に 1 回であり残便感が著しい。小 便は普通である。睡眠はやや浅く，夢が多い。食 欲はやや減退している。
〈他覚所見〉身長 $156 \mathrm{~cm}$, 体重 $48 \mathrm{~kg}$, BMI24.3。脈 候：浮やや弦, 舌候：背部に薄い微かに乾いた白 黄苔を，腹部に舌深静脈の怒張を認める。腹候： 腹力は中等度より軟, 腹壁は膨満し軟らかい。剣 状突起下から胸膈に向けての按圧により胸部不快 感を訴え, 胸骨両側の肋間部に軽度の按圧痛を触 知する。

［経 過］胸部不安感, 不眠傾向, 腹満, 便秘を目 標に厚朴七物湯を投与。服薬後 2 日目には残便感は 無くなり，胸部不快感，腹満，心下部の㾂塞感は漸 次消失した。第 7 病日, 咽喉部の痞塞感を訴えたた め厚朴七物湯合半夏厚朴湯に転方。以後の経過は良 好で 2 カ月後には廃薬した。

*厚朴七物湯：厚朴 $5 \mathrm{~g}$ ，枳実 $4 \mathrm{~g}$ ，采甘草 $2 \mathrm{~g}$ ，大

黄 $1 \mathrm{~g}$ ，大雵 $2 \mathrm{~g}$ ，桂皮 $2 \mathrm{~g}$ ，生葨 $1 \mathrm{~g}$ 。

*厚朴七物湯合半夏厚朴湯 : 厚朴 $5 \mathrm{~g}$, 枳実 $4 \mathrm{~g}$, 多

甘草 $2 \mathrm{~g}$, 大黄 $1 \mathrm{~g}$, 大雵 $2 \mathrm{~g}$, 桂皮 $2 \mathrm{~g}$, 生亩 $1 \mathrm{~g}$, 半夏 $6 \mathrm{~g}$, 茯苓 $5 \mathrm{~g}$, 蘇葉 $2 \mathrm{~g}$ 。

2 . 自験例の検討

a ）呈示例の病態

いずれも B 群に属す。第 1 例は腹膜透析に起因 する被囊性腹膜硬化症による反復するイレウスであ り，主たる症候は下焦に属している。身体の冷え， 足背動脈の脈候, 淡紅色の舌腹粘膜, 舌小帯近傍の 静脈拡張, 舌深静脈の膨化, 腹壁の軟弱, 臍下不仁, 大便の性状などを勘案し，この病態は腎虚を基盤と する虚熱によると診た。去甘草は，脾，胃よりも腎 の機能低下に基づく。古人は “補脾は補腎に如かず, 補腎は補脾に如かず32)”。と云い，概して腎虚には 補脾よりも補腎が先んずる。文献を涉猟しても, 腎 虚に対応す心゙き薬方で采甘草を含む薬方は極めて少 ない ${ }^{33)}$ 。本例は，また $4 /$ 週の透析による低カリウ 厶血症が認められたため, 治療当初より去采甘草と していたが水分摂取制限による咽乾を訴えたため小

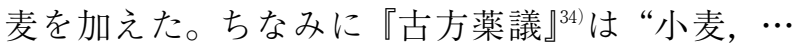
…渴を止め, 津液を滋し中気を和す。”と解説して いる。第 2 例は術後に発症した稂状態である。脈候, 微黄色を呈する厚い白湿苔, 著しい残便感と強い便 臭から，実熱による症候と診断した。第 3 例は気管 支喘息に合併した心身症である。脈候，白黄苔，著 しい残便感を実熱によるものとし，平素の気管支喘 息の症候から推して半夏厚朴湯と合方し著効を得た。 呈示の 3 例はともに腹満，便秘を主訴としており， 


\section{○胸骨両傍・肋間部の按圧 不快感・鈍痛

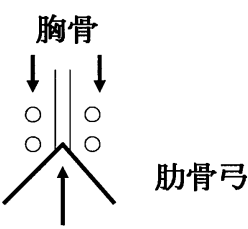 \\ ○剣状突起 $\rightarrow$ 胸膈への按圧 胸部㾂塞感}

図 3 指頭按圧による胸満の診断
表 2 自験例（3 週間以上継続して 服用したもの)

\begin{tabular}{|c|c|}
\hline 男:7例 女: & \\
\hline 節状態、秕病、統合失調症 & 16例 \\
\hline 慢性便秘症 & 15例 \\
\hline 腰痛症 & 4例 \\
\hline イレウスを併発する慢性腎不全 & 2例 \\
\hline 脳梗塞 & 2例 \\
\hline 気管支喘息 & 1例 \\
\hline
\end{tabular}

動摇などに起因する腸機能の病的充進あるいは低下 により，病的な陽気が根滞して内熱が生ずる。その 内熱が虚熱であれば，舌紅，腹部軟弱，大便乾結， 便意はあるも腹力なく排便に至らず腹脹を自覚する， などがみられ，また実熱ならば腹力があり，腹筋の 緊張を伴う腹満, 大便秘結, やや厚い白〜黄, 黄苔, 強い便臭などが認められた。胸部の不快感, 㾂塞感 は, 内熱の胸膈への上逆 (実熱), 上泛 (虚熱)に よるものと考える。この症候は，桂枝去药薬湯証の 胸満に通ずる。腹満の多くは脹満に属して柔らかく, 中脘の辺りに㾙塞感をともなっていた。長期服用例 を列挙する（表 3 )。症例 $1 ， 2$ は低カリウム血症 が認められたため去甘草加小麦としている。症例 3，7，8にみられる大建中湯との合方は慢性に経 過する便秘症に著効例が多く，寒熱の混淆した病態 に適応する。症例 5 は厚朴七物湯により腹満が去っ た後，去大黄とし胸満に即応したものである。

\section{考察}

\section{1 ．立方の趣旨}

立方について, 先述の $\mathrm{A}$ 群は概して桂枝湯と厚 朴三物湯との合方説である。この合方証では，厚朴 三物湯証が桂枝湯証より重い病態であり, 承気湯類 の効能を考慮し药薬を去ったものと考える。B 群で は, 薬量が A 群とは異なっているが, 䓎薬は用い られていない。この去药薬は, 先人の治験例, 自験 例から推して, 内熱が胸部へ波及して生ずる胸部症 候への対応と考える。

2 . 厚朴七物湯の薬量

·金貴要略

厚朴半斤，甘草三両，大黄三両，大雵十枚，枳実 五枚, 桂枝二両, 生姜五両。上七味, 以水一斗, 煮 取四升，温服八合，日三服。

\section{·三因極一病証方論}


表 3 長期服用例

\begin{tabular}{|c|c|c|c|c|}
\hline No. & 年齢·性 & 疾患 & 服用期間(月) & 加減·併用楽方、転方薬 \\
\hline 1 & 74·女 & $\begin{array}{l}\text { 慢性腎不全 } \\
\text { イレウスを併発 }\end{array}$ & 42 & 去甘草加小麦・服用中。 \\
\hline 2 & 54·女 & $\begin{array}{l}\text { 慢性腎不全 } \\
\text { イレウスを併発 }\end{array}$ & 21 & 去甘草加小麦・服用中。 \\
\hline 3 & 58·女 & 慢性便秘 & 21 & 大建中湯と合方・服用中。 \\
\hline 4 & 36·女 & 腰痛症 & 10 & 当掃莐薬散 (併用) \\
\hline 5 & 41·女 & 統合失調症 & 10 & 桂枝去芳藥加厚朴枳実に転方。 \\
\hline 6 & 71·男 & $\begin{array}{l}\text { パーキンソン病 } \\
\text { 慢性便私症 }\end{array}$ & 8 & 加龍骨恃蚛·服用中。 \\
\hline 7 & 74·女 & 腰痛症 & 7 & 大建中湯との合方·服用中。 \\
\hline 8 & 71·男 & 多発性腷梗塞 & 7 & $\begin{array}{l}\text { 大建中湯との合方から } \\
\text { 桂枝加大黄湯加厚朴积実に転方 }\end{array}$ \\
\hline
\end{tabular}

厚朴一両，甘草三銭，大黄三銭（各十二分：0.3 両), 大雵三個，枳実半両，桂心一分 (二銭半： 0.25 両), 姜七片。

右為蛙散，毎服四大銭，水蔶半，生姜七片，呆三 個〈三枚〉，煎七分，去滓，食前服。

世医得効方の解説は三因方と同文であるが，四大 銭を，四銭とし，震三個を三枚としている。（） 内の数值は，陶弘景の『序録 ${ }^{35}$ に記載されている 単位と宋の時代に「銖」の代わりに用いられた「銭」 の単位に基づき換算した值である。すなわち『序録』 では，一銖は十㯟，一分は六銖，一両は四分，一斤 は十六両であり，宋時代の「銭 $\rfloor^{36}$ は，一分を二銭 半としている。

三因方の厚朴，甘草，大黄，桂枝（桂心）の量は 金實の約 8 分の 1 に相当するが，その量比は，両書 ともに略近い值である。厚朴七物湯を桂枝去药薬湯 と厚朴三物湯の合方とすれば，効能として，前者に は解表の他，温中，通陽，祛寒があり，後者には承 気湯類に共通する行気，瀉熱，通腸がある。注目す べきは先人の治験，B 群の第 $1 ， 2 ， 4$ 例にみられ， 桂枝，生姜の大いなる増量である。これは寒涼の瀉 下剤を温性に改変したものと考える。条文方後の“下 利去大黄”の “去大黄” は後述のように病態が転変 することを考慮すべきである。著者は金匱の薬量に 従った。

3 . 厚朴七物湯証について
本方証の診断には慎重を要する。先述のように， 病態が外感に由来するか，あるいは陰虚内熱による かにより，その病態の虚実寒熱は異なる。概ね前者 が属するのは急性疾患であり，後者は慢性疾患であ る。運用するにあたっては, 以下の条文を参考にす ベきである。

21条：太陽病下之後, 脈促, 胸満者, 桂枝去药薬湯 主之。

234 条: 陽明病, 脈遅, 汗出多, 微悪寒者, 表未解 也，可発汗，宜桂枝湯。

腹満寒疝宿食病：痛而閉者，厚朴三物湯主之。

$\mathrm{A}$ 群の合方説では, 桂枝去药薬湯証と厚朴三物湯 証の併存に近似する病態を考慮せねばならない。桂 枝去药薬湯条の “胸満” は，厚朴七物湯条には記載 されていないが, 自験例の精神疾患では, 全例とも に胸満を認めており，胸満を本方の運用目標の一つ に挙げたい。また方後の “下利去大黄”とすれば， 桂枝去药薬湯加厚朴枳実となり，適応する病態は異 なる。さらに太陽証と陽明証の併存を説く234条は, 桂枝湯と厚朴三物湯の合方，すなわち厚朴七物湯と するか，あるいは桂枝湯と陽明病との併病で桂枝湯 による先表の治法とするかの鑑別に必須である。

4. 類証鑑別すべき薬方

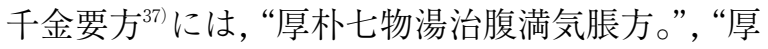
朴三物湯治腹満発熱数十日, 脈浮而数, 飲食如故 方。”をあり, 金匱要略の条文とは, 互い違いになっ 
ている。類聚方広義”は頭注に “病, 腹満し, 発熱 云々は，案ずるに脈経には以て厚朴三物湯症と為す, 而して此の方下に曰く, 腹満気脹を治すと。腹満気 脹は是，三物湯に宜しき所なり。疑ふらくば彼此， 方症相錯するのみ。”述べている。厚朴三物湯は, 枳実，厚朴が小承気湯より多く，病態は気滞が主で， 次いで榃熱, 水滞と続く。自験例には神経症, 精神 疾患が多くあり，本方の運用を考慮すべきである。 また稿本方輿輗 ${ }^{38)}$ は，厚朴三物湯，厚朴七物湯など の緩証に寛中湯（桂枝，生姜，药薬，甘草，大雵， 枳実，厚朴とあり薬量の記載はない)を推奨し, “寛 中八桂枝加药薬ニ少シ腹満ノツヨキ者ナリ。……若 シ大満二至ル者八厚朴三物湯，厚朴七物湯ナドノユ ク処ナリ。”述べている。寛中湯を桂枝加药薬湯 加厚朴枳実として腹満のみに限ればそうあるべきで ある。しかし，桂枝加药薬湯証は腹満を，桂枝去药 薬湯証は胸満を主証とし，適応病態を異にしている。 したがって，腹満とともに胸満が伏在する厚朴七物 湯証と稿本方輿輗の寛中湯とは，その軽重を論ずる ことはできない。

\section{5 。本方の運用}

著効，有効35例中の 28 例に，腹満と共に桂枝去药 薬湯証の伏在による胸満を認めた。それ故に胸膈・ 心下の精診が必須である。また“発熱，腹満，飲食 如故”の症候が外感によるものか，内傷によるもの かを勘案して虚実寒熱を診断し，また症候の軽重に より桂枝，生姜あるいは大黄の増減をも考慮すべき である。

\section{6 ．臨床応用}

現代の成書には，感冒に食傷を挟むもの，イレウ ス, 腹満を伴う胃腸疾患, 呼吸器疾患などが掲げら れているが，神経症，精神疾患，腰痛症にも適応す る症例があると思われる。神経・精神疾患における 抗精神病薬，頑固な腰痛症に鎮痛剂とともに併用さ れる抗不安薬の長期服用による便秘症がしばしばみ られる。これらの症例に胸満，腹満，便秘の症候を 目標に本方の運用も考慮されるべきである。但し症 候診断には精診，熟慮による虚実の判定が最も重要 であり，殊に虚弱者には注意して用いるべきである。

\section{結語}

先人の解説と治験，筆者等の有効例を礎に厚朴七 物湯証の考察を試みた。診断には，その病態が外感 によるものか，内傷によるものかを勘考し，後者に
属せば，内傷による陰陽内熱の虚実を考察すべきで ある。

附記 本稿は第59回日本東洋医学会学術総会（仙 台）に打いて発表した。

\section{参考文献}

1 ) 程雲来：金賈要略直解, 中巻二十五, 内閣文庫 - 漢 12044, コピー版, 高橋写真, 東京, 1990

2 ) 趙以徳衍義, 周陽俊補注: 金匱玉函経二註, 中国医学 大成八，巻十， 5 ，上海科学技術出版，上海， 1900

3 ) 張璐 : 張氏医通 (上), 722, 自由出版, 台北, 1992

4 ) 徐忠可: 金實要略論註, 133 , 人民衛生出版, 北京, 1993

5 ) 吳謙等：御篡醫宗金鑑（上）·訂正金實要略，483, 宏業書局，台北，1982

6 ) 尤在涇 : 金實心典, 巻中六, 旋風出版, 台北, 1974

7 ) 吉益東洞: 類聚方, 近世漢方医学書集成 12,215 , 名 著出版，東京， 1980

8 ）陳修園：金貴方歌括，上海科学技術出版， 54, 上海, 1963

9 ）尾台榕堂：類聚方広義，近世漢方医学書集成57，187, 名著出版，東京， 1980

10）曹頴甫：金賈発微，103，施風出版，台北，1972

11）唐容川：金匱要略浅注補正, 121 , 力行書局, 台北, 1993

12）李克光 - 張家礼主編 : 金實要略 - 高等中医薬院校教学 参考叢書，209，人民衛生出版，北京， 2008

13）紀藩主編：金匱要略. 中医薬学高級叢書, 295 , 人民 衛生出版，北京，2006

14）陳言撰：三因極一病証方論方，和刻漢籍医書集成第一 輯，146，エンタプライズ，東京，1988

15）王履撰：頭注医経溯洄集，和刻漢籍医書集成第六輯, 136-137，エンタプライズ，東京，1989

16）李経緯，春鐵濤主編：中医大辞典，228，1995

17）李経緯，春鐵濤主編：中医大辞典，627，1995

18）李杲：内外傷弁惑論 - 巻之一, 飲食労倦論, 和刻漢籍 医書集成第六輯，46，1989

19）李経緯，春鐵濤主編：中医大辞典，652，1995

20）家本誠一：黄帝内経 - 素問訳注 - 第三巻, 310, 医道 の日本社，横須賀，2009

21）危亦林撰：世医得効方，208，人民衛生出版，北京， 1990

22）魏荔㶦：金匱要略本義 ·金匱要略集註（山田業広選集 二)，204，名著出版，東京， 1984

23）福井楓亭 : 方読弁解，近世漢方医学書集成54，145, 263，名著出版，東京，1981

24）白川静：字統， 715, 平凡社，東京， 1987

25）内藤希哲：医経解惑論，近世漢方医学書集成 $70 ， 315$, 名著出版，東京， 1983

26）竜野一雄 : 感冒の経験 (二), 漢方と臨床 2 , 336, 雄 渾社，京都， 1979 
27）李克光 - 張家礼主編 : 金匱要略 - 高等中医薬院校教学 参考叢書，210，人民衛生出版，北京，2008

28）趙明鋭編：経方発揮，106，山西人民出版，山西，1982

29）原南洋：丵桂亭医事小事(1), 近世漢方医学書集成 18 , 447, 名著出版，東京， 1979

30）紀藩主編：金實要略・中医薬学高級叢書， 297 , 人民 衛生出版, 北京, 2006

31）福田佳弘：大承気湯証と陰虚証について, 漢方と臨床 43(5)，865，1996

32）内藤希哲：医経解惑論，近世漢方医学書集成 $70 ， 428$, 名著出版，東京， 1983

33）福田佳弘：少陰病・主薬方中における采甘草の果たす
役割について，日東医誌，57(6)，777-778，2006

34）浅田宗伯 : 木村長久校訓 ·古方薬議, 176 , 日本漢方 醫學會出版部, 1975

35）陶弘景: 序録: 岡本為人著・本草概説, p. 306より引 用, 創元社, 大阪, 1977

36）唐慎微：唐廣正解説 - 宋版 - 経史証類備急本草 (1), 132, オリエント出版, 大阪, 1992

37）孫思选 - 林億等校正 : 宋版 - 備急千金要方 (中), 512513，オリエント出版，大阪， 1989

38）有持桂里：稿本方舆輗 - 巻五，39, 谷口書店, 東京, 1972 